\title{
POTENSI PEMANFAATAN ATAP GEDUNG PUSAT PEMERINTAHAN KABUPATEN BADUNG UNTUK PLTS ROOFTOP
}

\author{
I Dewa Gde Yaya Putra Pratama ${ }^{1}$, I Nyoman Satya Kumara², I Nyoman Setiawan ${ }^{3}$ \\ Program Studi Teknik Elektro, Fakultas Teknik, Universitas Udayana, Denpasar-Bali \\ Email: yayaputrapratama@gmail.com ${ }^{1}$, ins kumara@yahoo.com ${ }^{2}$, setiawan@.unud.ac.id $^{3}$
}

\begin{abstract}
Abstrak
Dalam Rencana Usaha Penyediaan Tenaga Listrik PT Perusahaan Listrik Negara (RUPTL PT PLN) Tahun 2017 sampai dengan 2026, pemerintah menargetkan pengembangan Pembangkit Listrik Tenaga Surya (PLTS) sebesar 5000 MW pada tahun 2025. Salah satu upaya yang dapat dilakukan untuk mencapai target tersebut adalah dengan memanfaatkan gedung pemerintah sebagai tempat pemasangan PLTS. Penelitian ini bertujuan untuk mengetahui potensi daya dan produksi energi listrik jika atap gedung-gedung Pusat Pemerintahan Kabupaten Badung (Puspem Badung), Bali dipasang PLTS. Modul surya disimulasikan dipasang di sisi utara, timur, barat, dan selatan dari atap gedung Puspem Badung. Simulasi produksi energi listrik dilakukan dengan menggunakan software System Advisor Model (SAM). Hasil simulasi menunjukkan sisi utara mampu memproduksi energi listrik terbesar, yaitu 1.847.361 kWh/tahun. Total energi listrik yang dapat dihasilkan sebesar $6.169 .092 \mathrm{kWh} /$ tahun, jumlah ini setara dengan 124,72 \% dari konsumsi energi Puspem Badung sekarang ini.
\end{abstract}

Kata Kunci : Energi Terbarukan, System Advisor Model, Produksi Energi, Rooftop PV.

\section{Abstract}

In the RUPTL PT PLN Years 2017 untill 2026, the goverment aim to reach $5000 \mathrm{MW}$ of PV plant potential in 2025. But, until November 2016, the number of PV plant in Indonesia is around $11 \mathrm{MW}$. To reach the $5000 \mathrm{MW}$ target, many approach must be use. One of the approach is install PV plant on goverment buildings. Pusat Pemerintahan Kabupaten Badung (Puspem Badung) is a goverment buildings complex which located in Badung Regency, Bali is one of the goverment building that can be use for this approach. This paper aim to know the potency of electrical power dan electrical energy produced by Puspem Badung if the PV plant installed on the north, east, west, and south side of the roof. Electrical energy produced by PV plant is simulated by using System Advisor Model (SAM). From the simulation results, north side of the roof can produce energy of $1.847 .361 \mathrm{kWh} / \mathrm{year}$. From the analysis, the total energy that can be produced by PV plant is 6.169.092 kWh/year. This amount can supply Puspem Badung energy need by $124,72 \%$.

Keywords : Renewable Energy, System Advisor Model, Energy Production, Rooftop PV

\section{PENDAHULUAN}

Pemerintah telah mengeluarkan berbagai kebijakan mengenai energi baru dan terbarukan (EBT). Salah satu kebijakan yang dikeluarkan pemerintah adalah PP No. 79 Tahun 2014 Tentang Kebijakan Energi Nasional (KEN). Dalam kebijakan itu disebutkan bahwa untuk mencapai bauran energi yang optimal, pemerintah menargetkan penggunaan energi baru dan terbarukan paling sedikit sebesar $23 \%$ pada tahun 2025 dan paling sedikit sebesar $31 \%$ pada tahun 2050 [1]. Namun, berdasarkan Rencana Usaha Penyediaan Tenaga Listrik (RUPTL) PT PLN (Persero) Tahun 2017 sampai dengan 2026, hingga bulan November 2016 bauran energi dari energi baru dan terbarukan (EBT) hanya sebesar $12,9 \%$. Jika dirinci, bauran energi EBT yang terbesar datang dari air sebesar 7,8 \%, panas bumi 4,3\%, dan EBT lain sebesar 0,8\% [2]. Untuk kondisi di Bali, 
energi listrik yang berasal dari energi baru dan terbarukan hanya sekitar $1 \%$ dari total pembangkitan listrik di Bali [3], sehingga perlu ada upaya untuk meningkatkan jumlah energi listrik yang berasal dari EBT, baik di Bali maupun di Indonesia.

Indonesia yang terletak di wilayah khatulistiwa memiliki potensi rata-rata energi surya sebesar $4,8 \mathrm{kWh} / \mathrm{m}^{2} /$ hari [4]. Dari potensi tesebut, jumlah Pembangkit Listrik Tenaga Surya (PLTS) yang terpasang hingga bulan November tahun 2016 hanya sekitar 11 MW saja. Dalam RUPTL, pemerintah telah mencanangkan pengembangan potensi PLTS sebesar 5000 MW pada tahun 2025.

Melihat jumlah PLTS yang terpasang saat ini masih jauh dari target $5000 \mathrm{MW}$, maka diperlukan beragam upaya agar target tersebut dapat tercapai. Salah satu cara yang dapat dilakukan adalah dengan memanfaatkan atap gedung pemerintah. Gedung pemerintah umumnya beroperasi di siang hari, sehingga tenaga listrik yang dikonsumsi lebih banyak pada siang hari. Hal inilah yang menyebabkan PLTS cocok dipasang di gedung pemerintah, karena PLTS merupakan pembangkit listrik yang tergantung dengan sinar matahari. Dengan melakukan hal tersebut, diharapkan gedung pemerintah mampu mengurangi penggunaan energi listrik dari PLN.

PLTS yang akan dipasang di atap gedung memiliki beberapa keunggulan, diantaranya ruang untuk memasang PLTS sudah tersedia, sehingga tidak memerlukan lahan tambahan dan energi listrik yang dibangkitkan digunakan di tempat yang sama, sehingga investasi untuk transmisi dan distribusi tenaga listrik bisa dikurangi.

Kabupaten Badung merupakan salah satu dari delapan kabupaten dan satu kota di Provinsi Bali. Kabupaten Badung memiliki wilayah seluas $418,52 \mathrm{~km}^{2}$, atau mencakup 7,43 \% dari wilayah daratan Pulau Bali. Secara geografis, Kabupaten Badung terletak antara 8 $144^{\prime} 20^{\prime \prime}-8^{0} 50^{\prime} 52$ ', Lintang Selatan dan $115^{\circ} 05^{\prime} 03^{\prime}$ $115^{\circ} 26$ '51" Bujur Timur [5]. Berdasarkan data meteorologi dari NASA, Kabupaten Badung memiliki rata-rata iradiasi matahari sebesar 5,33 kWh/m²/hari. Jumlah ini lebih besar dibandingkan rata-rata iradiasi matahari Indonesia sebesar 4,8 $\mathrm{kWh} / \mathrm{m}^{2} /$ hari, sehingga Kabupaten Badung memiliki potensi untuk pengembangan PLTS.

Pada tahun 2016, Kabupaten Badung memiliki pendapatan sebesar 4,3 triliun Rupiah. Pendapatan terbesar berasal dari Pajak daerah, yaitu sebesar 2,9 triliun Rupiah. Sehingga jika dilihat dari sisi ekonomi, Kabupaten Badung memiliki potensi untuk melakukan pemasangan PLTS.

Pusat Pemerintahan Kabupaten Badung atau yang biasa disebut Puspem Badung merupakan salah satu kompleks pemerintahan yang dapat dijadikan percontohan dalam pemasangan PLTS. Puspem Badung berdiri di lahan seluas 46,6 ha yang berlokasi di Kelurahan Sempidi, Kecamatan Mengwi. Puspem Badung terdiri dari 18 gedung.

Penelitian ini bertujuan untuk mengetahui berapa potensi atap gedung Puspem Badung jika digunakan sebagai tempat pemasangan PLTS dan membandingkan dengan kebutuhan energi sekarang dan ke depan. Potensi atap gedung dihitung dengan menggunakan Google Earth. Data luas atap yang didapat akan diolah dengan menggunakan AutoCAD untuk menentukan banyaknya modul surya yang dapat dipasang di atap. Melalui penelitian ini, diharapkan dapat diketahui berapa besar energi yang dapat diproduksi PLTS yang dipasang di atap gedung Puspem Badung serta persentase energi yang dapat disuplai oleh PLTS. Hasil penelitian ini diharapkan dapat membantu Pemerintah Kabupatan Badung untuk memahami potensi daerah dalam ikut berkontribusi dalam pembangunan EBT dan khususnya PLTS rooftop.

\section{KAJIAN PUSTAKA}

\subsection{PLTS Rooftop}

PLTS rooftop merupakan PLTS yang dipasang di atas atap bangunan, baik rumah maupun komersial. PLTS rooftop merupakan PLTS skala kecil, yang biasanya berkapasitas $20 \mathrm{~kW}$. Di beberapa gedung komersial, PLTS rooftop dapat memiliki kapasitas mendekati $1 \mathrm{MW}$. Meskipun memiliki kapasitas yang lebih kecil, namun PLTS rooftop memiliki beberapa keunggulan, diantaranya dapat memanfaatkan lahan yang sudah ada, sehingga mengurangi biaya investasi lahan. Keunggulan lainnya adalah lebih mudah 
dan lebih murah untuk dihubungkan dengan sistem kelistrikan yang sudah ada [6].

\subsection{System Advisor Model}

System Advisor Model (SAM) merupakan sebuah software yang dapat digunakan untuk memperkirakan produksi energi dari pembangkit yang menggunakan energi terbarukan sebagai sumber energinya, termasuk PLTS yang menggunakan energi surya. SAM mampu mensimulasikan unjuk kerja dan model finansial dari suatu pembangkit, sehingga nantinya hasil simulasi itu dapat digunakan untuk memfasilitasi pengambilan keputusan bagi orang-orang yang terlibat di industri energi terbarukan, seperti manajer proyek, teknisi, maupun peneliti.

SAM awalnya dikembangkan oleh National Renewable Energy Laboratory (NREL) yang bekerja sama dengan Sandia National Laboratories pada tahun 2005. Pada awalnya SAM bernama Solar Advisor Model merupakan software khusus yang ditujukan untuk penggunaan internal di Program Teknologi Tenaga Surya Kemetrian Energi Amerika Serikat. NREL akhirnya merilis versi publik dari SAM pada tahun 2007. Pada 2011, seiring penambahan teknologi lain selain teknologi surya, software ini berganti nama dari Solar Advisor Model menjadi System Advisor Model.

\section{METODOLOGI PENELITIAN}

Penelitian dilakukan di Pusat Pemerintahan Kabupaten Badung. Tahapan penelitian adalah sebagai berikut: 1. Melakukan observasi dari gedung Puspem Badung untuk mengetahui konsidi gedung, letak geografis lokasi penelitian, serta mengumpulkan data-data yang diperlukan untuk menunjang penelitian.

2. Menghitung luas atap sisi utara, timur, selatan, dan barat dari masing-masing gedung dengan menggunakan Google Earth.

3. Menentukan banyaknya modul surya yang dapat dipasang di atap gedung.

4. Menghitung potensi daya berdasarkan banyaknya modul surya yang dapat dipasang di atap gedung.

5. Melakukan simulasi dengan menggunakan SAM untuk menentukan produksi energi dari PLTS.
6. Produksi energi yang dihasilkan nantinya dibandingkan dengan energi yang diperlukan Puspem untuk menentukan besarnya energi yang dapat disuplai oleh PLTS.

7. Menentukan pendapatan yang dihasilkan oleh Pemerintah Kabupaten Badung jika kelebihan energi PLTS dijual ke PLN.

\section{HASIL DAN PEMBAHASAN}

\subsection{Gambaran Umum Puspem Badung}

Pusat Pemerintahan Kabupaten

Badung (Puspem Badung) merupakan sebuah kompleks gedung pemerintah milik Pemerintah Kabupaten Badung yang terletak di Kelurahan Sempidi, Kecamatan Mengwi, Kabupaten Badung. Puspem Badung terletak pada koordinat $08^{0} 14^{\prime} 17^{\prime \prime}$ $08^{0} 50$ '57" Lintang Selatan (LS) $115^{\circ} 05^{\prime} 02^{\prime \prime}-$ 115 15'09" Bujur Timur (BT). Gedung Puspem Badung mulai dibangun pada tahun 2007. Pembangunan ini bertujuan untuk mengantikan gedung Puspem Badung Dharma Praja yang terbakar akibat kerusuhan pada tahun 1999. Pembangunan dilakukan dalam tiga tahap. Yaitu tahap pertama pada tahun 2007, tahap kedua pada tahun 2008, dan tahap ketiga pada tahun 2009. Peresmian gedung ini dilakukan pada tahun 2010 oleh Menteri Dalam Negeri Gamawan Fauzi [7]. Puspem Badung berdiri di atas lahan seluas 46,6 ha, di mana di areal Puspem badung sendiri terdapat 18 gedung. Masing-masing gedung diisi oleh Organisasi Perangkat Daerah (OPD), di mana setiap gedung diisi oleh 1 hingga 3 OPD.

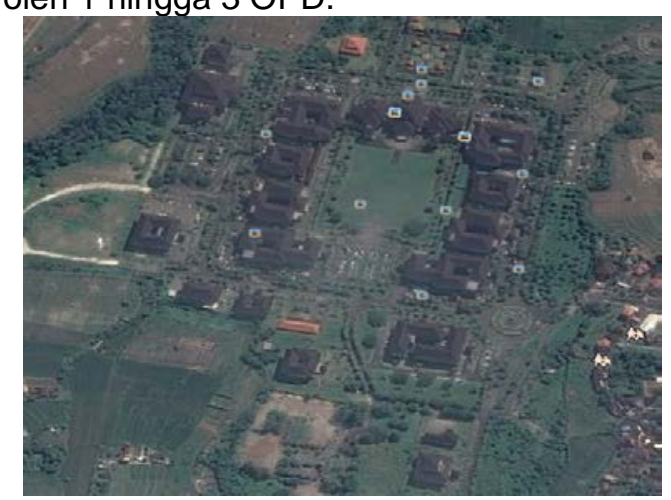

Gambar 1. Pusat Pemerintahan Kabupaten Badung

\subsection{Sistem Kelistrikan Puspem Badung}

Daya listrik yang digunakan di gedung Puspem Badung berasal dari dua sumber, 
yaitu PLN dan genset. Daya listrik dari PLN akan MVMDP dan akan menuju trafo. Selanjutnya, aliran listrik dari trafo dan genset akan disalurkan menuju LVMDP dan kemudian disalurkan ke masingmasing SDP. Dari SDP kemudian disalurkan ke masing-masing beban.

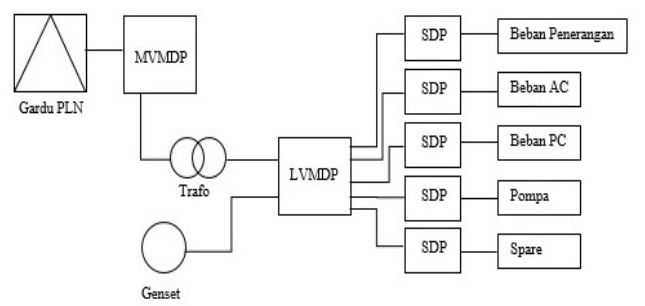

Gambar 2. Sistem Kelistrikan Puspem Badung

Konsumsi energi Puspem Badung selama tahun 2016 dapat dilihat pada tabel 1.

Tabel 1. Konsumsi Energi Puspem Badung Tahun 2016

\begin{tabular}{|l|c|}
\hline \multicolumn{1}{|c|}{ Bulan } & $\begin{array}{c}\text { Konsumsi Energi Puspem Badung } \\
(\mathrm{kWh})\end{array}$ \\
\hline Januari & $454.365,77$ \\
\hline Februari & $349.666,03$ \\
\hline Maret & $405.879,72$ \\
\hline April & $426.282,03$ \\
\hline Mei & $440.815,39$ \\
\hline Juni & $402.398,06$ \\
\hline Juli & $339.521,03$ \\
\hline Agustus & $384.874,28$ \\
\hline September & $347.784,91$ \\
\hline Oktober & $467.816,15$ \\
\hline November & $478.186,24$ \\
\hline Desember & $448.825,48$ \\
\hline Total & $4.946 .415,09$ \\
\hline
\end{tabular}

Grafik Konsumsi Energi Puspem Badung Tahun 2016 600.000

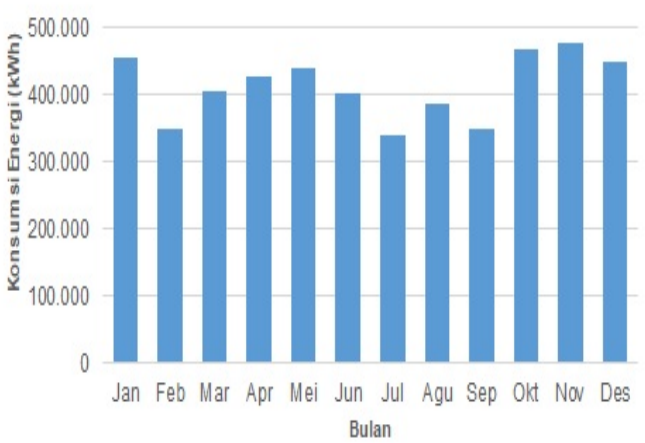

Gambar 3. Grafik Konsumsi Energi Puspem Badung Tahun 2016

Dari tabel 1, dapat dilihat bahwa konsumsi energi Puspem dalam setahun sebesar
4.964.415,09 kWh. Konsumsi energi terbesar terjadi pada bulan November dengan konsumsi energi sebesar 478.186,24 kWh, sedangkan produksi energi terendah terjadi pada bulan Juli dengan konsumsi energi sebesar 339.521,03 kwh.

\subsection{Luas Atap Gedung Puspem Badung}

Untuk mengetahui potensi dari daya listrik yang mampu dihasilkan atap gedung Puspem Badung, langkah pertama yang dilakukan adalah mencari luas atap gedung dari tiap gedung yang ada di Puspem Badung. Seperti yang sudah dijelaskan sebelumya bahwa terdapat 18 gedung di Puspem Badung, sehingga masing-masing gedung dihitung luas atapnya. Keempat sisi dari atap gedung, yaitu sisi utara, sisi timur, sisi barat, dan sisi selatan dihitung luasnya. Hal ini dikarenakan masing-masing sisi atap gedung menghadap ke sudut azimuth yang berbeda. Luas atap dicari menggunakan Google Earth dan hasilnya dapat dilihat pada tabel 2 dan 3.

Tabel 2. Luas Atap Gedung Puspem Badung Sisi Utara dan Timur

\begin{tabular}{|l|c|c|}
\hline \multirow{2}{*}{ Unit/Dinas } & \multicolumn{2}{|c|}{ Luas Atap Tiap Sisi (m2) } \\
\cline { 2 - 3 } & Utara & Timur \\
\hline Unit 5 & $1.310,50$ & $1.003,00$ \\
\hline Unit 8 & $1.035,02$ & $1.082,08$ \\
\hline Unit 9 & 818,11 & 645,57 \\
\hline Unit 10 & 465 & 399 \\
\hline Unit 11 & 759 & 493,3 \\
\hline Unit 12 & 825,25 & 633,25 \\
\hline Unit 14 & $1.104,66$ & 646,08 \\
\hline Unit 15 & 465 & 399 \\
\hline Unit 16 & 759 & 495 \\
\hline Unit 17 & 825,25 & 633,25 \\
\hline Unit 25 & 448,1 & 431,66 \\
\hline Unit 31 & 651,27 & 649,04 \\
\hline Koperasi & 299,42 & 97,07 \\
\hline Perpustakaan & 196,57 & 221,5 \\
\hline Kantin & 204,77 & 39,13 \\
\hline $\begin{array}{l}\text { Dinas } \\
\text { Kearsipan }\end{array}$ & 281,84 & 320,92 \\
\hline Depo Arsip & 284,94 & 256,2 \\
\hline $\begin{array}{l}\text { Dinas } \\
\text { Pemadam }\end{array}$ & 146,26 & 57,23 \\
\hline Total & $10.879,95$ & $8.502,29$ \\
\hline
\end{tabular}

Tabel 3. Luas Atap Gedung Puspem Badung Sisi Barat dan Selatan

\begin{tabular}{|l|c|c|}
\hline \multirow{2}{*}{ Unit/Dinas } & \multicolumn{2}{|c|}{ Luas Atap Tiap Sisi (m2) } \\
\cline { 2 - 3 } & Barat & Selatan \\
\hline Unit 5 & $1.003,00$ & $1.310,50$ \\
\hline Unit 8 & $1.082,12$ & $1.035,87$ \\
\hline Unit 9 & 663,95 & 818,08 \\
\hline Unit 10 & 399 & 465 \\
\hline Unit 11 & 493,3 & 759 \\
\hline Unit 12 & 633,25 & 825,25 \\
\hline
\end{tabular}




\begin{tabular}{|l|c|c|} 
Unit 14 & 646,08 & $1.104,66$ \\
\hline Unit 15 & 399 & 465 \\
\hline Unit 16 & 495 & 759 \\
\hline Unit 17 & 633,26 & 825,24 \\
\hline Unit 25 & 431,66 & 448,1 \\
\hline Unit 31 & 649,04 & 651,27 \\
\hline Koperasi & 97,07 & 299,42 \\
\hline Perpustakaan & 221,5 & 196,57 \\
\hline Kantin & 39,13 & 204,77 \\
\hline $\begin{array}{l}\text { Dinas } \\
\text { Kearsipan }\end{array}$ & 320,92 & 281,84 \\
\hline Depo Arsip & 256,2 & 284,94 \\
\hline $\begin{array}{l}\text { Dinas } \\
\text { Pemadam }\end{array}$ & 78,28 & 146,26 \\
\hline Total & $8.541,77$ & $10.880,76$ \\
\hline
\end{tabular}

Pada tabel 2 dan 3, dapat dilihat bahwa sisi terluas adalah sisi selatan dengan luas sebesar 10.880,76 $\mathrm{m}^{2}$. Sedangkan sisi timur memiliki luas terkecil dengan luas sebesar $8.502,29 \mathrm{~m}^{2}$.

\subsection{Perancangan PLTS}

Untuk melakukan simulasi produksi energi dengan menggunakan SAM, diperlukan input dari dua komponen PLTS, yaitu modul surya dan inverter. SAM menyediakan database modul surya dan inverter dari berbagai produsen untuk dipilih oleh pengguna dalam melakukan simulasi.

Dalam pemilihan modul surya, ada dua faktor yang diperhatikan. Yang pertama adalah ketersediaan modul surya di Indonesia dan yang kedua adalah adanya data modul surya tersebut dalam database SAM. Modul surya yang mampu memenuhi kedua kriteria tersebut adalah modul surya Canadian Solar Maxpower CS6U-340M yang diproduksi oleh Canadian Solar. Spesifikasinya dapat dilihat pada tabel 4.

Sedangkan dalam pemilihan inverter, selain memperhatkan ketersediaan barang di Indonesia dan adanya data inverter tersebut dalam database SAM, inverter yang dipilih harus memiliki kapasitas kerja yang mendekati output PLTS. Untuk inverter yang digunakan dalam simulasi ini adalah SUNNY TRIPOWER 24000TL yang dibuat oleh SMA America. Untuk spesifikasinya dapat dilihat pada tabel 5 .

Tabel 4. Spesifikasi Modul Surya Canadian Solar Maxpower CS6U-340M

\begin{tabular}{|l|l|}
\hline \multicolumn{2}{|c|}{ Standard Test Condition (STC) } \\
\hline \multicolumn{2}{|c|}{ Electrical Data } \\
\hline Pmax & $340 \mathrm{~W}$ \\
\hline Vmp & $37,9 \mathrm{~V}$ \\
\hline Imp & $8,97 \mathrm{~A}$ \\
\hline
\end{tabular}

\begin{tabular}{|l|l|} 
Voc & $46,2 \mathrm{~V}$ \\
\hline Isc & $9,48 \mathrm{~A}$ \\
\hline Modul Efficiency & $17,49 \%$ \\
\hline Operating Temperature & $-40^{0} \mathrm{C} \sim+85^{0} \mathrm{C}$ \\
\hline Power Tolerance & $0 \sim+5 \mathrm{~W}$ \\
\hline Max. System Voltage & $1000 \mathrm{~V}$ \\
\hline \multicolumn{2}{|c|}{ Mechanical Data } \\
\hline Cell Type & Mono-crystalline, 6 inch \\
\hline Cell Arrangement & $72(6 \times 12)$ \\
\hline Dimensions & $1960 \times 992 \times 40 \mathrm{~mm}$ \\
\hline Weight & $22,4 \mathrm{~kg}(49,4 \mathrm{lbs})$ \\
\hline \multicolumn{2}{|c|}{ Temperature Characteristics } \\
\hline Pmax & $-0,41 \% /{ }^{0} \mathrm{C}$ \\
\hline Voc & $-0,31 \% /{ }^{0} \mathrm{C}$ \\
\hline Isc & $0,05 \%{ }^{0} \mathrm{C}$ \\
\hline NMOT & $43 \pm 2^{0} \mathrm{C}$ \\
\hline
\end{tabular}

Tabel 5. Spesifikasi Inverter Sunny Tripower 24000TL

\begin{tabular}{|c|c|}
\hline Technical Data & 24000TL \\
\hline \multicolumn{2}{|l|}{ Input (DC) } \\
\hline $\begin{array}{l}\text { Max. usable DC power (@ } \cos \phi= \\
\text { 1) }\end{array}$ & $24500 \mathrm{~W}$ \\
\hline Max. DC voltage & $1000 \mathrm{~V}$ \\
\hline Rated MPPT voltage range & $450 \mathrm{~V}$ to $800 \mathrm{~V}$ \\
\hline MPPT operating voltage range & $\begin{array}{l}150 \mathrm{~V} \text { to } 1000 \\
\mathrm{~V}\end{array}$ \\
\hline Number of MPP tracker inputs & 2 \\
\hline $\begin{array}{l}\text { Max. input current / per MPP } \\
\text { tracker input }\end{array}$ & 66 A / 33 A \\
\hline \multicolumn{2}{|l|}{ Output (AC) } \\
\hline AC nominal power & $24000 \mathrm{~W}$ \\
\hline Max. AC apparent power & $24000 \mathrm{VA}$ \\
\hline Output phases / line connections & 3/3-N-PE \\
\hline Nominal AC voltage & $\begin{array}{l}480 / 277 \mathrm{~V} \\
\text { WYE }\end{array}$ \\
\hline AC voltage range & $244 \mathrm{~V}$ to $305 \mathrm{~V}$ \\
\hline AC grid frequency / range & $50 \mathrm{~Hz}, 60 \mathrm{~Hz}$ \\
\hline Max. output current & $29 \mathrm{~A}$ \\
\hline Harmonics & $<3 \%$ \\
\hline Max. efficiency / CEC efficiency & $98.5 \% / 98.0 \%$ \\
\hline Dimensions (W / H / D) in mm & $665 / 650 / 265$ \\
\hline Weight & $55 g$ (121 lbs) \\
\hline
\end{tabular}

Modul surya akan disusun secara seri dan paralel, sebelum kemudian dihubungkan ke inverter. Untuk skematik dari PLTS dapat dilihat pada gambar 4 . 


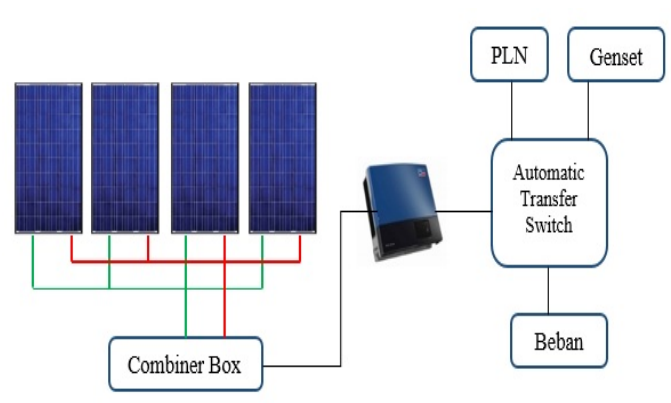

Gambar 4. Skematik PLTS

\subsection{Menentukan Jumlah Modul Surya}

Setelah mengetahui luas atap untuk keempat sisi dari seluruh gedung di Puspem Badung dan juga menentukan modul surya serta inverter yang akan digunakan, langkah selanjutnya adalah menentukan banyaknya modul surya yang dapat dipasang di atap gedung Puspem Badung. Untuk mengetahui banyaknya modul surya yang dapat dipasang di atap gedung Puspem Badung, disimulasikan dengan menggunakan AutoCAD. Hal ini dikarenakan tiap gedung memiliki bentuk yang berbeda-beda, di mana terdapat sisi yang memiliki bentuk berupa segitiga, jajaran genjang, maupun trapesium, sehingga saat modul surya yang berbentuk persegi panjang dipasang, akan menyisakan ruang kosong. Salah satu bentuk atap gedung yang terdapat di Puspem Badung dapat dilihat pada gambar 5. Sedangkan untuk jumlah modul surya yang dapat dipasang di atap gedung Puspem Badung dapat dilihat pada tabel 6.

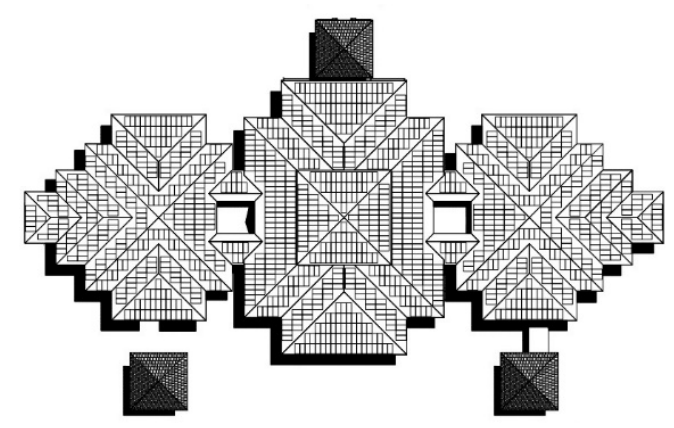

Gambar 5. Atap Gedung Unit 8

Tabel 6. Jumlah Modul yang Dapat dipasang pada Atap Gedung Puspem Badung

\begin{tabular}{|l|c|c|c|c|}
\hline \multirow{2}{*}{ Unit/Dinas } & \multicolumn{4}{|c|}{ Jumlah Modul Yang Dapat } \\
& \multicolumn{4}{|c|}{ Dipasang } \\
\cline { 2 - 5 } & Utara & Timur & Barat & Selatan \\
\hline Unit 5 & 525 & 365 & 397 & 525 \\
\hline
\end{tabular}

\begin{tabular}{|l|c|c|c|c|}
\hline Unit 8 & 277 & 307 & 307 & 277 \\
\hline Unit 9 & 234 & 181 & 196 & 224 \\
\hline Unit 10 & 162 & 146 & 146 & 168 \\
\hline Unit 11 & 287 & 167 & 166 & 284 \\
\hline Unit 12 & 328 & 253 & 252 & 328 \\
\hline Unit 14 & 389 & 186 & 207 & 399 \\
\hline Unit 15 & 166 & 140 & 140 & 166 \\
\hline Unit 16 & 291 & 176 & 176 & 291 \\
\hline Unit 17 & 326 & 241 & 254 & 326 \\
\hline Unit 25 & 167 & 153 & 153 & 167 \\
\hline Unit 31 & 268 & 268 & 268 & 268 \\
\hline Koperasi & 116 & 36 & 36 & 116 \\
\hline Perpustakaan & 68 & 76 & 76 & 68 \\
\hline Kantin & 64 & 10 & 10 & 64 \\
\hline $\begin{array}{l}\text { Dinas } \\
\text { Kearsipan }\end{array}$ & 74 & 110 & 110 & 74 \\
\hline Depo Arsip & 93 & 87 & 87 & 93 \\
\hline $\begin{array}{l}\text { Dinas } \\
\text { Pemadam }\end{array}$ & 46 & 22 & 18 & 46 \\
\hline Total & 3.881 & 2.924 & 2.999 & 3.884 \\
\hline
\end{tabular}

Berdasarkan tabel 6, dapat dilihat bahwa sisi selatan dari atap gedung dapat dipasangi modul surya paling banyak, yaitu sebanyak 3.884 modul surya. Sedangkan sisi timur dari atap gedung dapat dipasangi modul surya paling sedikit, yaitu sebanyak 2.924 modul surya.

Jumlah modul surya yang dapat dipasang di atap gedung Puspem Badung pada tabel 6 selanjutnya digunakan untuk menentukan potensi daya listrik dari masing-masing atap gedung. Untuk mencari potensi energi dari tiap-tiap gedung, dapat dilakukan dengan persamaan sebagai berikut:

Total Daya $=$ Jumlah Modul $x$ Pmax

Pmax modul berdasarkan dari modul surya yang digunakan. Pada penelitian ini, modul surya yang digunakan adalah Canadian Solar Maxpower CS6U-340M. Sesuai data pada tabel 4, modul surya yang digunakan memiliki Pmax sebesar $340 \mathrm{~W}$. Sedangkan untuk jumlah modul, data yang digunakan adalah data pada tabel 6.

Dengan menggunakan persamaan (1), maka didapatkan total daya untuk sisi utara dan sisi timur dari atap gedung Puspem Badung, yang hasilnya dapat dilihat pada tabel 7.

Tabel 7. Potensi Daya Puspem Badung Sisi Utara dan Timur

\begin{tabular}{|l|c|c|}
\hline \multirow{2}{*}{ Unit/Dinas } & \multicolumn{2}{|c|}{ Total Daya (Wp) } \\
\cline { 2 - 3 } & Utara & Timur \\
\hline
\end{tabular}




\begin{tabular}{|l|c|c|} 
Unit 5 & 178.500 & 124.100 \\
\hline Unit 8 & 94.180 & 104.380 \\
\hline Unit 9 & 79.560 & 61.540 \\
\hline Unit 10 & 55.080 & 49.640 \\
\hline Unit 11 & 97.580 & 56.780 \\
\hline Unit 12 & 111.520 & 86.020 \\
\hline Unit 14 & 132.260 & 63.240 \\
\hline Unit 15 & 56.440 & 47.600 \\
\hline Unit 16 & 98.940 & 59.840 \\
\hline Unit 17 & 110.840 & 81.940 \\
\hline Unit 25 & 56.780 & 52.020 \\
\hline Unit 31 & 91.120 & 91.120 \\
\hline Koperasi & 39.440 & 12.240 \\
\hline Perpustakaan & 23.120 & 25.840 \\
\hline Kantin & 21.760 & 3.400 \\
\hline Kearsipan & 25.160 & 37.400 \\
\hline Depo Arsip & 31.620 & 29.580 \\
\hline Pemadam & 15.640 & 7.480 \\
\hline Total & 1.319 .540 & 994.160 \\
\hline
\end{tabular}

Dari tabel 7, dapat dilihat bahwa sisi utara memiliki potensi daya sebesar 1.319.540 Wp, sedangkan sisi timur memiliki potensi daya sebesar 994.160 Wp. Sisi utara memiliki potensi daya yang lebih besar karena mampu dipasangi modul surya lebih banyak dibandingkan sisi Timur, sesuai yang terdapat pada tabel 6 .

Sedangkan untuk potensi daya pada sisi barat dan sisi selatan dari atap gedung Puspem Badung juga dicari dengan menggunakan cara yang sama seperti tabel 7. Untuk hasilnya dapat dilihat pada tabel 8.

Tabel 8. Potensi Daya Puspem Badung Sisi Barat dan Selatan

\begin{tabular}{|l|c|c|}
\hline \multirow{2}{*}{ Unit/Dinas } & \multicolumn{2}{|c|}{ Total Daya (Wp) } \\
\cline { 2 - 3 } & Barat & Selatan \\
\hline Unit 5 & 134.980 & 178.500 \\
\hline Unit 8 & 104.380 & 94.180 \\
\hline Unit 9 & 66.640 & 76.160 \\
\hline Unit 10 & 49.640 & 57.120 \\
\hline Unit 11 & 56.440 & 96.560 \\
\hline Unit 12 & 85.680 & 111.520 \\
\hline Unit 14 & 70.380 & 135.660 \\
\hline Unit 15 & 47.600 & 56.440 \\
\hline Unit 16 & 59.840 & 98.940 \\
\hline Unit 17 & 86.360 & 110.840 \\
\hline Unit 25 & 52.020 & 56.780 \\
\hline Unit 31 & 91.120 & 91.120 \\
\hline Koperasi & 12.240 & 39.440 \\
\hline Perpustakaan & 25.840 & 23.120 \\
\hline Kantin & 3.400 & 21.760 \\
\hline Kearsipan & 37.400 & 25.160 \\
\hline Depo Arsip & 29.580 & 31.620 \\
\hline Pemadam & 6.120 & 15.640 \\
\hline Total & 1.019 .660 & 1.320 .560 \\
\hline
\end{tabular}

Dari tabel 8 dapat dilihat bahwa sisi selatan memiliki potensi daya sebesar 1.320. 560 Wp, sedangkan sisi barat memiliki potensi daya sebesar 1.019.660 Wp. Dari tabel 7 dan tabel 8 dapat dilihat bahwa sisi selatan memiliki potensi daya terbesar dibandingkan sisi lainnya. Hal ini sesuai dengan tabel 6 , di mana sisi selatan merupakan sisi yang paling banyak dapat dipasangi modul surya. Sedangkan sisi timur merupakan sisi dengan potensi energi terendah, hal ini disebabkan karena jumlah modul surya yang dapat dipasang di sisi timur lebih rendah dibandingkan dengan sisi lainnya.

\subsection{Simulasi Produksi Energi PLTS Pada Atap Gedung Puspem Badung} Simulasi produksi energi Puspem Badung dilakukan dengan menggunakan SAM. Pada SAM dapat diketahui potensi energi surya dari Puspem Badung. Potensi energi surya Puspem Badung dapat dilihat pada tabel 9 dan gambar 6 .

Tabel 9. Potensi Energi Surya Puspem Badung

\begin{tabular}{|l|c|}
\hline \multicolumn{1}{|c|}{ Bulan } & Potensi Energi (kWh/bulan) \\
\hline Januari & 125.749 \\
\hline Februari & 116.782 \\
\hline Maret & 146.596 \\
\hline April & 150.035 \\
\hline Mei & 169.742 \\
\hline Juni & 186.946 \\
\hline Juli & 181.646 \\
\hline Agustus & 186.262 \\
\hline September & 140.411 \\
\hline Oktober & 151.834 \\
\hline November & 148.301 \\
\hline Desember & 107.512 \\
\hline
\end{tabular}

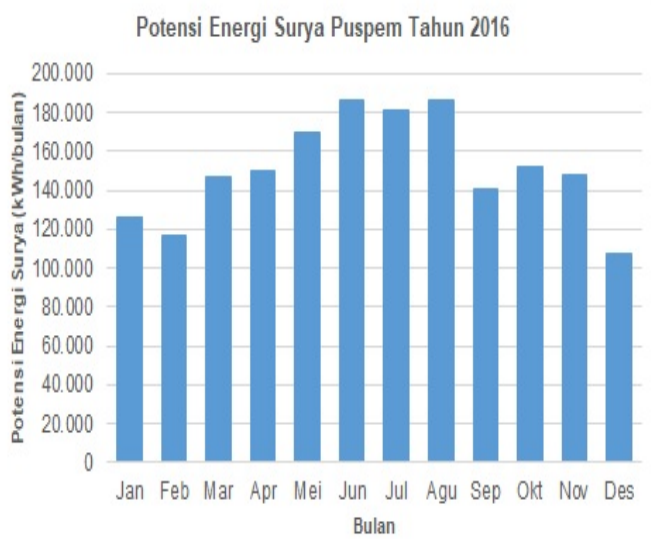

Gambar 6. Potensi Energi Surya Puspem Badung 
Untuk melakukan simulasi produksi energi dari PLTS yang dipasang di atap gedung Puspem Badung dengan menggunakan SAM, tahapan yang dilakukan adalah sebagai berikut:

1. Memilih model simulasi yang akan digunakan, dalam penelitian ini, model yang akan digunakan adalah No Financial Model. Setelahnya diperlukan beberapa input. Yang pertama adalah input mengenai lokasi pemasangan PLTS. Lokasi pemasangan PLTS adalah Puspem Badung yang terletak di -8.603073 LS, 115.178591 BT. Untuk wilayah Indonesia, data cuaca dapat di-download pada situs PVGis.

2. Melakukan pemilihan modul surya yang akan digunakan. Seperti pada tabel 4 , modul surya yang akan digunakan adalah Canadian Solar MAXPOWER CS6U-340M.

3. Melakukan pemilihan inverter. Inverter yang akan digunakan adalah Sunny Tripower 24000TL dengan spesifikasi yang dapat dilihat pada tabel 5.

4. Pada System Sizing, input untuk kapasitas PLTS yang digunakan akan diisi sesuai tabel IV. Untuk sudut kemiringan, diisi dengan $35^{\circ}$, sesuai dengan sudut kemiringan atap gedung. Sedangkan untuk sudut azimuth, untuk sisi utara diisi dengan $12^{\circ}$, untuk sisi timur diisi dengan $102^{\circ}$, untuk sisi selatan diisi dengan $192^{\circ}$, dan untuk sudut $282^{\circ}$.

5. Untuk shading diisi dengan nilai 0 , karena dalam penelitian ini, nilai shading diabaikan. Sedangkan untuk losses, dibiarkan inputan default dari SAM [8]. Hasil simulasi dapat dilihat pada tabel 10 dan 11 .

Tabel 10. Hasil Simulasi PLTS Rooftop Puspem Badung Sisi Utara dan Timur

\begin{tabular}{|l|c|c|}
\hline Unit & $\begin{array}{c}\text { Utara (kWh/ } \\
\text { tahun) }\end{array}$ & $\begin{array}{c}\text { Timur (kWh/ } \\
\text { tahun) }\end{array}$ \\
\hline Unit 5 & 253.451 & 146.849 \\
\hline Unit 8 & 134.383 & 127.239 \\
\hline Unit 9 & 110.923 & 73.424 \\
\hline Unit 10 & 79.223 & 60.276 \\
\hline Unit 11 & 134.383 & 66.914 \\
\hline Unit 12 & 158.445 & 100.371 \\
\hline Unit 14 & 190.147 & 73.424 \\
\hline Unit 15 & 79.223 & 53.570 \\
\hline Unit 16 & 141.459 & 73.424 \\
\hline Unit 17 & 158.445 & 100.371 \\
\hline Unit 25 & 79.223 & 60.276 \\
\hline Unit 31 & 126.725 & 106.901 \\
\hline Koperasi & 53.065 & 13.332 \\
\hline
\end{tabular}

\begin{tabular}{|l|c|c|} 
Perpustakaan & 29.624 & 26.785 \\
\hline Kantin & 31.541 & 6.552 \\
\hline Dinas Kearsipan & 31.694 & 39.850 \\
\hline Depo Arsip & 39.611 & 33.457 \\
\hline Dinas Pemadam & 15.796 & 6.582 \\
\hline Rata-Rata & 102.631 & 64.978 \\
\hline Total & 1.847 .361 & 1.169 .597 \\
\hline
\end{tabular}

Tabel 11. Hasil Simulasi PLTS Rooftop Puspem Badung Sisi Barat dan Selatan

\begin{tabular}{|l|c|c|}
\hline \multicolumn{1}{|c|}{ Unit } & $\begin{array}{c}\text { Barat (kWh/ } \\
\text { tahun) }\end{array}$ & $\begin{array}{c}\text { Selatan (kWh/ } \\
\text { tahun) }\end{array}$ \\
\hline Unit 5 & 207.185 & 220.821 \\
\hline Unit 8 & 164.026 & 117.209 \\
\hline Unit 9 & 101.898 & 96.620 \\
\hline Unit 10 & 77.704 & 69.014 \\
\hline Unit 11 & 86.318 & 117.209 \\
\hline Unit 12 & 129.447 & 138.028 \\
\hline Unit 14 & 101.898 & 165.635 \\
\hline Unit 15 & 69.078 & 69.014 \\
\hline Unit 16 & 94.713 & 123.784 \\
\hline Unit 17 & 129.447 & 138.028 \\
\hline Unit 25 & 77.704 & 69.014 \\
\hline Unit 31 & 138.001 & 110.410 \\
\hline Koperasi & 17.226 & 47.077 \\
\hline Perpustakaan & 34.539 & 27.600 \\
\hline Kantin & 7.519 & 27.481 \\
\hline $\begin{array}{l}\text { Dinas } \\
\text { Kearsipan }\end{array}$ & 50.949 & 27.600 \\
\hline Depo Arsip & 43.159 & 34.507 \\
\hline Dinas Pemadam & 8.533 & 13.739 \\
\hline Rata-Rata & 85.519 & 89.599 \\
\hline Total & 1.539 .344 & 1.612 .790 \\
\hline
\end{tabular}

Dari tabel 10 dan 11 dapat dilihat bahwa berdasarkan hasil simulasi, sisi utara merupakan sisi yang mampu memproduksi energi listrik terbesar, yaitu sebesar 1.847.361 kWh/tahun. $\mathrm{Hal}$ ini dikarenakan Pulau Bali terletak di sebelah selatan garis khatulistiwa, sehingga matahari berada di utara. Hal ini menyebabkan sinar matahari yang diterima PLTS yang dipasang pada sisi utara atap gedung menerima sinar matahari lebih banyak dibandingkan sisi lainnya.

\subsection{Energi Yang Dapat Disuplai Oleh PLTS}

Pada tabel 1 dapat dilihat bahwa total konsumsi energi dari Puspem Badung selama setahun sebesar 4.964.415,09 kWh. Untuk mengetahui seberapa besar persentase energi listrik yang dapat disuplai oleh PLTS berdasarkan hasil simulasi pada tabel 10 dan 11 terhadap total konsumsi energi listrik Puspem Badung pada tabel 1, dapat dilihat pada tabel 12. 
Tabel 12. Persentase Energi Yang Dapat Disuplai Oleh PLTS

\begin{tabular}{|l|c|c|}
\hline \multicolumn{1}{|c|}{ Sisi } & Energi (kWh/tahun) & Persentase (\%) \\
\hline Utara & 1.847 .361 & 37,35 \\
\hline Timur & 1.169 .597 & 23,65 \\
\hline Barat & 1.539 .344 & 31,12 \\
\hline Selatan & 1.612 .790 & 32,61 \\
\hline Total & 6.169 .092 & 124,72 \\
\hline
\end{tabular}

Dari tabel 12, dapat dilihat bahwa sisi utara mampu menyuplai energi listrik terbesar, yaitu sebesar 37,35\%, sedangkan sisi timur merupakan sisi menjadi yang terendah karena hanya mampu menyuplai energi sebesar 23,65 \%. Total energi yang dapat disuplai oleh PLTS yang dipasang di sisi utara, timur, barat, dan selatan atap gedung Puspem Badung sebesar 6.169.092 kWh/tahun. Jumlah ini mampu menyuplai kebutuhan energi listrik Puspem Badung sebesar $124,72 \%$ dari total energi listrik yang dikonsumsi Puspem Badung.

Dari tabel 12 dapat dilihat bahwa energi yang diproduksi oleh PLTS lebih banyak dari yang diperlukan oleh Puspem Badung. Kelebihan energi ini dapat dijual ke PLN yang nantinya dapat menjadi pemasukan bagi Kabupaten Badung. Berdasarkan Peraturan Menteri ESDM Nomor 12 Tahun 2017 dan Keputusan Menteri ESDM Nomor 1772 Tahun 2018, Biaya Pokok Penyediaan Pembangkitan (BPP Pembangkitan) di Bali sebesar Rp 911/kWh [9],[10]. Kelebihan energi serta besarnya pendapatan Puspem Badung jika menjual listrik hasil PLTS ke PLN dapat dilihat pada tabel 13.

Tabel 13. Kelebihan Energi yang dihasilkan PLTS Rooftop Puspem Badung

\begin{tabular}{|l|c|c|}
\hline \multicolumn{1}{|c|}{ Bulan } & $\begin{array}{c}\text { Kelebihan Energi } \\
(\mathrm{kWh})\end{array}$ & Pendapatan (Rp) \\
\hline Januari & $114.733,10$ & 104.521 .855 \\
\hline Februari & $133.066,78$ & 121.223 .832 \\
\hline Maret & $126.816,45$ & $115.529 .782,30$ \\
\hline April & $51.177,05$ & $46.622 .296,19$ \\
\hline Mei & $59.837,53$ & $54.511 .990,74$ \\
\hline Juni & $117.868,10$ & $107.377 .836,40$ \\
\hline Juli & $185.412,45$ & $168.910 .740,10$ \\
\hline
\end{tabular}

\begin{tabular}{|l|c|c|} 
Agustus & $195.388,78$ & $177.999 .174,90$ \\
\hline September & $138.001,12$ & $125.719 .016,70$ \\
\hline Oktober & $138.604,35$ & $126.268 .561,90$ \\
\hline November & $159.425,10$ & $145.236 .269,70$ \\
\hline Desember & $31.486,60$ & $28.684 .295,33$ \\
\hline Total & $1.451 .817,40$ & 1.322 .605 .651 \\
\hline
\end{tabular}

Dari tabel 13 dapat dilihat bahwa kelebihan energi yang dihasilkan oleh PLTS sebesar 1.451.817,40 kWh/tahun. Jika kelebihan energi tersebut dijual ke PLN, maka pemerintah Kabupaten Badung mendapatkan pemasukan sebesar 1,3 miliar Rupiah/tahun.

\section{KESIMPULAN}

Berdasarkan hasil pengukuran dengan menggunakan Google Earth, total luas atap gedung Puspem Badung sebesar 38.804,77 m2. Di mana, dari luas atap tersebut, jumlah modul surya yang mampu dipasang sebanyak 13.688 buah modul surya. Sehingga, berdasarkan jumlah modul yang dapat dipasang di atap gedung, Puspem Badung memiliki potensi daya sebesar 4.653.920 kW. Sisi selatan dari atap gedung memiliki potensi daya terbesar, yaitu sebesar 1.320.560 kW. Hal ini disebabkan karena sisi selatan memiliki luas atap terluas, sehingga mampu dipasangi modul surya lebih banyak dibandingkan sisi lainnya.

Berdasarkan hasil simulasi menggunakan SAM, didapatkan bahwa PLTS yang dipasang di sisi utara atap gedung mampu menghasilkan energi listrik terbesar, yaitu sebesar 1.847.361 kWh/tahun. Sisi utara mampu menghasilkan energi listrik terbesar karena Pulau Bali terletak di sisi selatan khatulistiwa, sehingga posisi matahari berada di sisi utara khatulistiwa. Hal ini menyebabkan sinar matahari yang diterima oleh PLTS yang dipasang di sisi utara lebih besar dibandingkan dengan sisi lainnya.

PLTS yang dipasang di seluruh sisi atap gedung Puspem Badung mampu menghasilkan energi sebesar 6.169.092 kWh/tahun. Jumlah ini mampu menyuplai kebutuhan energi Puspem Badung sebanyak 124,72 \%. Kelebihan energi yang dihasilkan oleh PLTS sebesar 1.451.817,40 kWh/tahun, dan jika kelebihan energi tersebut dijual, maka pemerintah Kabupaten Badung akan mendapatkan pemasukan sebesar 1,3 miliar Rupiah/tahun. 


\section{DAFTAR PUSTAKA}

[1] Peraturan Pemerintah Republik Indonesia No. 79 Tahun 2014 Tentang Kebijakan Energi Nasional (KEN).

[2] Kementerian Energi dan Sumber Daya Mineral. Rencana Usaha Penyediaan Tenaga Listrik PT. Perusahaan Listrik Negara (Persero) Tahun 2017 s.d. 2026, 2017.

[3] I N. S. Kumara, W. G. Ariastina, W. Sukerayasa, I. A. D. Giriantari. "On the potential and progress of renewable electricity generation in Bali". 2014 6th International Conference on Information Technology and Electrical Engineering (ICITEE). 2014.

[4] A. Rahardjo, Herlina, H. Safruddin. "Optimalisasi Pemanfaatan Sel Surya Pada Bangunan Komersial Secara Terintegrasi Sebagai Bangunan Hemat Energi". Prosiding Seminar Nasional Sains dan Teknologi-II. 2008: 56-65.

[5] BPS Kabupaten Badung. "Kabupaten Badung Dalam Angka 2017". Badung: BPS Kabupaten Badung. 2017.

[6] Asian Developmet Bank. "Handbook for Solar Development in Asia". Manila: Asian Development Bank. 2014.

[7] I G. M. Raharja. "Simulasi Desain dengan Citra Kronoskopi Gedung Pusat Pemerintahan Kabupaten Badung Sebuah Pembuktian Teori Dekonstruksi Derrida". Jurnal Seni Budaya Mudra .2015. Vol. 30, No. 2.: 153-164.

[8] P.A. Sujana, I N. S. Kumara, I. A. D. Giriantari. "Pengaruh Kebersihan Modul Surya Terhadap Unjuk Kerja PLTS". EJournal SPEKTRUM. 2015. Vol. 2, No. 3.: 49-54.

[9] Peraturan Menteri ESDM No. 12 Tahun 2017 Tentang Pemanfaatan Sumber Energi Terbarukan Untuk Penyediaan Tenaga Listrik.

[10] Keputusan Menteri ESDM Nomor 1772 K/20/MEM/2018 Tentang Besaran Biaya Pokok Penyediaan Pembangkitan PT Perusahaan Listrik Negara (Persero) Tahun 2017. 